\title{
Onset of Cholinergic Efferent Synaptic Function in Sensory Hair Cells of the Rat Cochlea
}

\author{
Isabelle Roux, ${ }^{1}$ Eric Wersinger, ${ }^{1}$ J. Michael McIntosh, ${ }^{3}$ Paul A. Fuchs, ${ }^{1,2}$ and Elisabeth Glowatzki ${ }^{1,2}$ \\ ${ }^{1}$ Department of Otolaryngology, Head and Neck Surgery, The Center for Hearing and Balance and the Center for Sensory Biology, and ${ }^{2}$ Department of \\ Neuroscience, The Johns Hopkins University School of Medicine, Baltimore, Maryland 21205, and ${ }^{3}$ Department of Biology, Department of Psychiatry, \\ University of Utah, Salt Lake City, Utah 84112-0840
}

In the developing mammalian cochlea, the sensory hair cells receive efferent innervation originating in the superior olivary complex. This input is mediated by $\alpha 9 / \alpha 10$ nicotinic acetylcholine receptors (nAChRs) and is inhibitory due to the subsequent activation of calciumdependent SK2 potassium channels. We examined the acquisition of this cholinergic efferent input using whole-cell voltage-clamp recordings from inner hair cells (IHCs) in acutely excised apical turns of the rat cochlea from embryonic day 21 to postnatal day 8 (P8). Responses to $1 \mathrm{~mm}$ acetylcholine (ACh) were detected from P0 on in almost every IHC. The ACh-activated current amplitude increased with age and demonstrated the same pharmacology as $\alpha 9$-containing nAChRs. Interestingly, at P0, the ACh response was not coupled to SK2 channels, so that the initial cholinergic response was excitatory and could trigger action potentials in IHCs. Coupling to SK current was detected earliest at P1 in a subset of IHCs and by P3 in every IHC studied. Clustered nAChRs and SK2 channels were found on IHCs from P1 on using Alexa Fluor 488 conjugated $\alpha$-bungarotoxin and SK2 immunohistochemistry. The number of nAChRs clusters increased with age to 16 per IHC at P8. Cholinergic efferent synaptic currents first appeared in a subset of IHCs at P1 and by P3 in every IHC studied, contemporaneously with ACh-evoked SK currents, suggesting that SK2 channels may be necessary at onset of synaptic function. An analogous pattern of development was observed for the efferent synapses that form later (P6-P8) on outer hair cells in the basal cochlea.

\section{Introduction}

In the mammalian cochlea, inner and outer hair cells (IHCs and OHCs) are innervated by efferent cholinergic neurons originating from the superior olivary complex. The cholinergic efferent input to the IHCs disappears shortly after hearing onset, whereas efferent neurons continue to innervate the mature OHCs (for review, see Simmons, 2002). For both IHCs and OHCs, the response to applied acetylcholine (ACh) and efferent synaptic activity exhibit similar properties (Glowatzki and Fuchs, 2000; Oliver et al., 2000; Katz et al., 2004). ACh activates an ionotropic ACh receptor most likely formed by $\alpha 9$ and $\alpha 10$ nicotinic acetylcholine receptor (nAChR) subunits (Elgoyhen et al., 1994, 2001).

Received May 31, 2011; revised Aug. 13, 2011; accepted Aug. 29, 2011.

Author contributions: I.R., E.W., J.M.M., P.A.F., and E.G. designed research; I.R. and E.W. performed research; J.M.M. contributed unpublished reagents/analytic tools; I.R. and E.W. analyzed data; I.R., E.W., P.A.F., and E.G. wrote the paper.

This work was supported by National Institute on Deafness and Other Communication Disorders (NIDCD) R01DC006476 to E.G., European Molecular Biology Organization (EMBO) ALTF 952-2006, and National Organization of Hearing Research (NOHR) Foundation Seed Research Award to I.R., NIDCD R01DC000276 to P.F., GM48677 and MH53631 to J.M.M., NIH R24DK064388 to the Hopkins Basic Research Digestive Disease Development Core Center and Ross Confocal Facility, and NIDCD P30 DC005211 to the Center for Hearing and Balance Core Grant. We thank Dr. Chris T. Bond and Pr. John P. Adelman for kindly providing antibodies against SK2.

The authors declare no competing financial interests.

Correspondence should be addressed to Elisabeth Glowatzki, The Johns Hopkins School of Medicine, Departments of Otolaryngology Head and Neck Surgery and Neuroscience, 720 Rutland Avenue, Ross 824, Baltimore MD 21205. E-mail: eglowat1@jhmi.edu.

E. Wersinger's present address: SENSORION Hôpital St-Eloi, 80 rue Augustin Fliche, BP 74103, 34090 Montpellier, France.

DOI:10.1523/JNEUROSCI.2743-11.2011

Copyright $\odot 2011$ the authors $\quad 0270-6474 / 11 / 3115092-10 \$ 15.00 / 0$
These nAChRs show little desensitization and are relatively permeable to calcium, compared with most other nicotinic receptors (Weisstaub et al., 2002; Gómez-Casati et al., 2005). Calcium influx through the nAChR subsequently activates calcium-dependent small conductance potassium channels (SK2) (Fuchs and Murrow, 1992a,b; Nenov et al., 1996; Tucker and Fettiplace, 1996; Yamamoto et al., 1997; Dulon et al., 1998; Nie et al., 2004). Due to this coupling between the excitatory $\alpha 9 / \alpha 10 \mathrm{nAChR}$ and SK2, both application of ACh and efferent synaptic activity hyperpolarize the IHC membrane potential and inhibit IHC activity (Kros et al., 1998; Glowatzki and Fuchs, 2000).

The function of the transient efferent innervation to IHCs is still unknown. However, efferent modulation of IHC activity may be one of the factors that set firing properties of auditory nerve fibers before hearing onset (Glowatzki and Fuchs, 2000; Tritsch et al., 2007; Tritsch et al., 2010; Johnson et al., 2011) and thereby may influence refinement of wiring in the auditory pathway.

The expression of functional nAChRs and SK2 channels seems to be tightly coupled in hair cells. SK currents and ACh-activated currents show similar developmental expression profiles in rat IHCs, appearing in the first postnatal week and disappearing after hearing onset (Katz et al., 2004; Marcotti et al., 2004). In addition, the lack of an ACh response in postnatal IHCs of SK2-deficient animals had led to the hypothesis that SK2 may be necessary for the acquisition of functional nAChRs in the IHC plasma membrane (Marcotti et al., 2004; Johnson et al., 2007; Kong et al., 2008). Loss of SK2 expression also results in long-term loss of efferent innervation of OHCs (Murthy et al., 2009). 
To better understand the role of nAChRs and SK2 channels in hair cells, we closely examined the onset of the efferent input and its functional characteristics in IHCs from excised rat apical cochlear coils. ACh-activated currents were found in most IHCs from P0 on. From P1 to P3, nAChRs clustering, SK2 channels clustering and their functional association with the ACh response, as well as the appearance of efferent synaptic currents, occurred with strikingly similar progression, suggesting that efferent synaptic function is contemporaneous with, and may require, SK2 channel expression. We also demonstrate a "developmental switch" whereby the hair cell's cholinergic response changes from excitatory to inhibitory during synapse formation.

\section{Materials and Methods}

Animal procedures. Sprague Dawley albino rats (CD IGS rats) were obtained from Charles River Laboratory. Animals were studied from embryonic day 21 (E21) to postnatal day 21 (P21). Males and females were placed together in the afternoon. Appearance of the vaginal plug the following morning was representative of gestation day 1 (E1). E22 was defined as P0. As much as possible, experiments were conducted on pups from the same litter. Data were pooled in $24 \mathrm{~h}$ time windows. Animals from at least three litters were studied per each $24 \mathrm{~h}$ data point. For recordings from $\mathrm{OHCs}$, the day of birth was defined as $\mathrm{P} 0$. Animals were deeply anesthetized (isoflurane or $\mathrm{CO}_{2}$ inhalation), decapitated, and inner ears were quickly removed from the temporal bones. For experiments with pups at E21, the death of the female breeder was ensured by cervical dislocation. All experimental procedures involving animals were approved by the Johns Hopkins University Animal Care and Use Committee.

Electrophysiological recordings. Excised cochlear coils of E21 to P21 rats were placed into a chamber under an upright microscope (Axioskope, Zeiss) and superfused with external solution at 2-3 $\mathrm{ml} / \mathrm{min}$ (chamber volume $\sim 2 \mathrm{ml}$ ). IHCs and OHCs were visualized on a monitor via a $40 \times$ water-immersion objective, $4 \times$ magnification, differential interference contrast optics using a green filter, and camera with contrast enhancement (C2400-07; Hamamatsu). The pipette solutions were (in mM): 135 $\mathrm{KCl}, 3.5 \mathrm{MgCl}_{2}, 0.1 \mathrm{CaCl}_{2}, 5$ EGTA, 5 HEPES, $2.5 \mathrm{Na}_{2}$ ATP for IHCs or 120 Kgluconate, $20 \mathrm{KCl}, 5$ EGTA, 5 HEPES, $2.5 \mathrm{Na}_{2} \mathrm{ATP}, 0.1 \mathrm{Ca}^{2+}, 3.5$ $\mathrm{MgCl}_{2}$, and $10 \mathrm{Na}$-Phosphocreatine for OHCs [290 mOsm, pH 7.2 $(\mathrm{KOH})]$. The external solution (ExS) contained the following (in $\mathrm{mm}$ ): $5.8 \mathrm{KCl}, 144 \mathrm{NaCl}, 1.3 \mathrm{CaCl}_{2}, 0.9 \mathrm{MgCl}_{2}, 0.7 \mathrm{NaH}_{2} \mathrm{PO}_{4}, 5.6$ D-glucose, and 10 HEPES [ $300 \mathrm{mOsm}$, pH 7.4 ( $\mathrm{NaOH})$ ]. For external solutions with 40 or $80 \mathrm{~mm} \mathrm{KCl}, \mathrm{KCl}$ was substituted for $\mathrm{NaCl}$. Voltages were corrected off-line for liquid junction potentials ( $\sim-4 \mathrm{mV}$ for IHC recordings and $\sim-11 \mathrm{mV}$ for OHC recordings).

Recording pipettes were fabricated from $1 \mathrm{~mm}$ borosilicate glass (WPI). Pipettes were pulled with a multistep horizontal puller (Sutter), pipette resistances were $\sim 3-5 \mathrm{M} \Omega$, and series resistances were $\sim 7-14$ $\mathrm{M} \Omega$. Voltages were not corrected for the voltage drop across the uncompensated series resistance. Pipettes were coated with Sylgard (Dow Corning). Recordings were performed at room temperature (RT; $22-25^{\circ} \mathrm{C}$ ). Currents were recorded either with an Axopatch 200B amplifier (IHCs recordings) or with a Multiclamp 700B amplifier (OHCs recordings) (Molecular Devices), low-pass filtered at $5-10 \mathrm{kHz}$, and digitized at $20-50 \mathrm{kHz}$ with a Digidata $1440 \mathrm{~A}$ board. Data were stored with PClamp10.2 software (Molecular Devices).

Drugs were dissolved in external solution to their final concentrations from frozen stocks daily and applied either directly to the bath with a flow rate of $\sim 2-3 \mathrm{ml} / \mathrm{min}$ (OHCs) or by using a gravity-driven flow pipette (100 $\mu \mathrm{m}$ diameter), positioned $\sim 300 \mu \mathrm{m}$ from the recorded IHC and connected to a VC- 6 channel valve controller (Warner Instrument).

Alexa Fluor 488 conjugated $\alpha$-bungarotoxin $(\alpha$-Btx) was purchased from Invitrogen, methyllycaconitine citrate from Tocris Bioscience. $\alpha$-RgIA was synthesized as previously described (Ellison et al., 2006). All other chemicals, including acetylcholine chloride, apamin, strychnine hydrochloride, and (+)-tubocurarine hydrochloride, were purchased from Sigma.

Data were analyzed off-line using Clampfit 10.2 (Molecular Devices), Minianalysis (Synaptosoft), and Origin 8 (OriginLab). For presentation, data were low-pass filtered off-line using a 8-pole Bessel filter with a 1 $\mathrm{kHz}$ cutoff, and reduced 50 times. For postsynaptic currents analysis, data were low-pass filtered off-line using an 8-pole Bessel filter with a 2 $\mathrm{kHz}$ cutoff. Events were identified using a search routine for event detection in Minianalysis and confirmed by eye. Events had to be larger than twice the root mean square of the average noise level. The time constant of decay was obtained by fitting the $10-90 \%$ decay of events with a monoexponential function.

Values are presented as mean \pm SDs unless indicated otherwise. Statistical analyses were performed by ANOVA followed by Bonferroni's post hoc test for multiple comparisons. Association of two phenomena studied in the same cell was tested using Fisher's exact test. $p<0.05$ was considered significant.

$\alpha$-Bungarotoxin labeling. To label nAChRs in cochlear tissue, cochleae from P0 to P3 and P8 rats were rapidly microdissected in cold extracellular solution followed by incubation for $5 \mathrm{~min}$ in Alexa Fluor 488 conjugated $\alpha$-Btx at RT. The Alexa Fluor 488 conjugated $\alpha$-Btx (lot $57550 \mathrm{~A})$ was diluted at $10 \mu \mathrm{g} / \mathrm{ml}(\sim 1.18 \mu \mathrm{M})$ in extracellular solution as used for electrophysiology $(\mathrm{ExS})$ at $\mathrm{RT}$, and used at a $5 \times$ concentration for lot 825458, to gain the same sensitivity. After a 5 min wash in ExS, the cochleae were further incubated for $1 \mathrm{~min}$ in $3 \mu \mathrm{M}$ FM4-64FX (Invitrogen), to counter-label the hair cells, before washing again for $5 \mathrm{~min}$ in ExS at RT. Cochleae were mounted on slides in a drop of FluorSave mounting medium (Calbiochem) and immediately observed using a confocal laserscanning microscope (LSM 510 META, Zeiss) with a $40 \times$ oil objective N.A. 1.3 ( $z$-axis step size: $0.50 \mu \mathrm{m}$ ). Only one $z$-stack acquisition was acquired per preparation. For each age and each experiment, a preparation incubated without $\alpha$-Btx was used as control of the tissue's autofluorescence to define the intensity threshold above which the detected signal was attributed to the presence of $\alpha$-Btx labeling.

Immunolabeling. Cochleae were microdissected from rats at P0 to P8, perfused through the round and oval windows (for P3 and older), and fixed for $1 \mathrm{~h}$ at $4^{\circ} \mathrm{C}$ with $4 \%$ paraformaldehyde (Electron Microscopy Sciences) prepared in PBS, pH 7.4. After three washes in PBS, cochleae were microdissected to facilitate access of the antibodies to the tissue. Whole-mount preparations were then incubated for $1 \mathrm{~h}$ at RT in a blocking and permeabilizing solution (BPS: PBS with $20 \%$ of normal goat serum and $0.25 \%$ Triton X-100), before incubation for $72 \mathrm{~h}$ at $4{ }^{\circ} \mathrm{C}$ with the primary antibodies diluted in the same solution. Rabbit antibodies against myosin VI (Sigma) and purified guinea-pig antibodies against SK2 (C39, kind gift from John P. Adelman and Chris T. Bond, Vollum Institute, Oregon Health Sciences University, OR) were used as primary antibodies at 1:500 and $2.7 \mu \mathrm{g} / \mathrm{ml}$ dilutions, respectively. After two 15 min washes in PBS $0.25 \%$ Triton X-100 and one wash in BPS, the samples were incubated for $1 \mathrm{~h}$ at RT with the secondary antibodies diluted at 1:800 in BPS. Alexa Fluor $488 \mathrm{~F}\left(\mathrm{ab}^{\prime}\right)_{2}$ fragment of goat anti-rabbit and Alexa Fluor 555 goat anti-guinea pig (Invitrogen) were used as secondary antibodies. Samples were rinsed $3 \times$ for $15 \mathrm{~min}$ in PBS at RT before the organs of Corti were mounted on slides and observed using a LSM 510 META confocal microscope with a $20 \times$ objective and a PlanApochromat $100 \times$ oil objective N.A. 1.4 ( $z$-axis step size: $0.20 \mu \mathrm{m}$ ). Analysis and reconstruction were performed using LSM Image Examiner (Zeiss) and Volocity 4.2.1 software (Improvision). The images presented were taken from the apical turn of the cochlea, to match the area of recording. No labeling was detected when the primary antibodies were omitted.

\section{Results}

nAChR currents in apical IHCs were detected first at P0

The efferent innervation in the rat cochlea reaches the vicinity of the IHCs and makes initial contacts with IHCs between birth (P0) and $2 \mathrm{~d}$ after birth (P2), as shown by anterograde labeling with the diffusable carbocyanines dye DiI applied to the cut central axons of olivocochlear neurons (Cole and Robertson, 1992; Bruce et al., 2000) (for review, see Simmons, 2002). This process matures progressively from base to apex of the cochlear coil; only few efferent fibers have been found in close vicinity of apical IHCs at P0 compared with a larger population of efferent fibers close to 
basal IHCs at the same time point (Cole and Robertson, 1992). Immunoreactivity to choline acetyltransferase (ChAT), the synthesizing enzyme of $\mathrm{ACh}$, has been identified at birth in the region close to the IHCs in the basal coil of the cochlea and has been shown to develop with a similar basal to apical progression (Merchán Pérez et al., 1994). A similar temporal expression pattern for other proteins related to cholinergic synaptic transmission such as the vesicular acetylcholine transporter and the high-affinity choline transporter further confirms the arrival of efferent terminals close to the IHCs in the early postnatal period (Bergeron et al., 2005; Osman et al., 2008) (for review, see Simmons et al., 2011).

To determine when the IHCs begin to express functional nAChRs, whole-cell voltage-clamp recordings were performed from IHCs in acutely excised apical turns of the rat cochlea, focusing on ages close to the time when efferent fibers reach the IHCs (E21-P3). As a reference, recordings were also performed at P8 and P21. These time points were chosen as it has been shown earlier that the IHC response to $100 \mu \mathrm{M}$ ACh reaches its maximum around P8 and disappears during the third postnatal week, after the onset of hearing in both rats and mice (Katz et al., 2004; Marcotti et al., 2004). In the present study, a higher concentration of ACh (1 mM) was applied via a local perfusion for $\sim 30 \mathrm{~s}$, to assure that even small ACh-induced currents could be detected. A reproducible inward current $>10 \mathrm{pA}$ was accepted as a positive response to ACh.

At $\mathrm{E} 21$, no response to $1 \mathrm{~mm}$ ACh was detected ( $n=8 \mathrm{IHCs} ; 3$ animals). Between P0 and P8, 98\% of 115 IHCs studied responded to $1 \mathrm{~mm}$ ACh with an inward current (Fig. 1A,B). The amplitude of these $\mathrm{ACh}$ currents recorded at $-94 \mathrm{mV}$ increased significantly between $\mathrm{P} 0$ and $\mathrm{P} 3$ from $22 \pm 13 \mathrm{pA}(n=19)$ to $285 \pm 164 \mathrm{pA}(n=6)$. IHCs slightly grow over the recorded age range. Therefore, for a comparison between ages, in Figure $1 B$, ACh current amplitudes are given relative to the IHC membrane capacitance that is proportional to the IHC membrane area. At $\mathrm{P} 8$, compared with $\mathrm{P} 0$, the normalized ACh response increased 37-fold, and at P21, the normalized ACh response in the responding cells $(3 / 5)$ was reduced to values smaller than those at P0. In summary, nAChR currents in apical IHCs were detected first at $\mathrm{P} 0$. From $\mathrm{P} 0$ on, during the first postnatal week, an ACh response was detected in almost every IHC recorded, and the ACh current amplitude increased with age.

\section{Early postnatal ACh currents are mostly mediated by $\alpha 9$ -} containing nAChRs

Pharmacological blockers were used to assure that the small early postnatal responses to ACh were mediated by $\alpha 9$ and/or $\alpha 9 / \alpha 10$ nAChRs (summarized as $\alpha 9$-containing nAChRs from here on). At P0 to P2, ACh currents in IHCs were completely and reversibly blocked by $10 \mu \mathrm{M}(+)$-tubocurarine, a general nAChR blocker
(P0: $n=2, \mathrm{P} 1: n=6, \mathrm{P} 2: n=2)$, and by $10 \mu \mathrm{M}$ strychnine (P0: $n=2, \mathrm{P} 1: n=7 / 8, \mathrm{P} 2: n=3)$ that has been shown to antagonize homomeric $\alpha 7$ - and $\alpha 9$-containing nAChRs reversibly and competitively (Anand et al., 1993; Elgoyhen et al., 1994, 2001; Gerzanich et al., 1994; Sgard et al., 2002) (Fig. 1C). ACh currents were also partially and reversibly blocked by $300 \mathrm{~nm} \alpha$-conotoxin RgIA ( $\alpha$-RgIA) (Ellison et al., 2006), a subtype-specific blocker of $\alpha 9$ containing nAChRs (P1: $n=3 / 4, \mathrm{P} 2: n=4)$ (Fig. $1 D)$. This pharmacological profile, similar to that of ACh currents in IHCs at later developmental stages (Elgoyhen et al., 1994; Glowatzki and Fuchs, 2000; Katz et al., 2004; Ellison et al., 2006), confirms that the early postnatal ACh currents recorded here are mostly mediated by $\alpha 9$-containing nAChRs. These results are consistent with previous RT-PCR and in situ hybridization experiments indicating that rat IHCs express $\alpha 9$ mRNA at E18 and later (Luo et al., 1998; Simmons and Morley, 1998), and $\alpha 10$ mRNA from E21 through P15 (Morley and Simmons, 2002).

\section{At $\mathrm{P} 0$, the ACh response in IHCs is not coupled to SK2 channels}

To test whether the ACh response in IHCs of young rats includes the activation of small conductance calcium-dependent potassium channels (SK2 channels), as has been described for older animals (Glowatzki and Fuchs, 2000; Oliver et al., 2000; Katz et al., 2004; Marcotti et al., 2004), we obtained current-voltage 


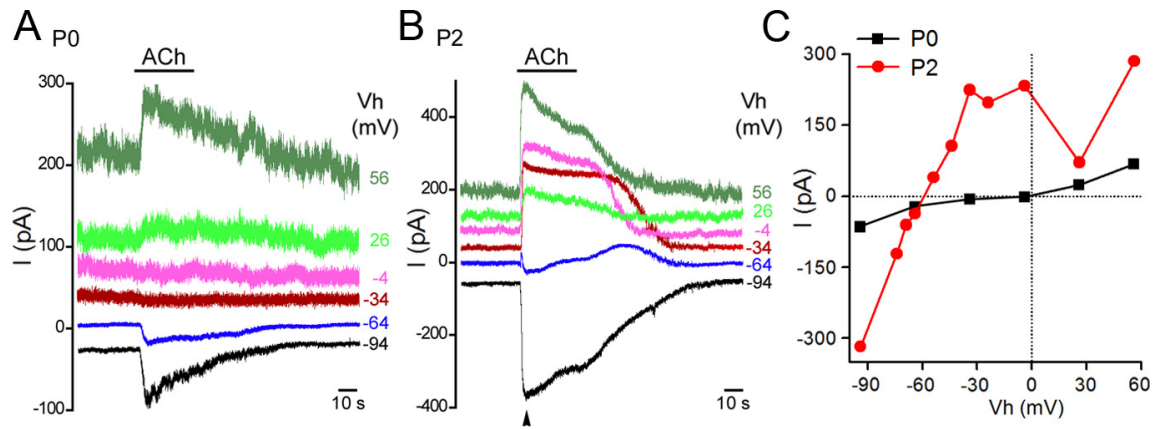

D
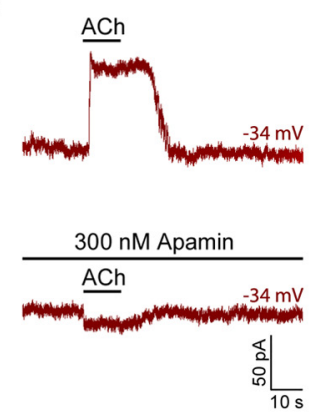

E
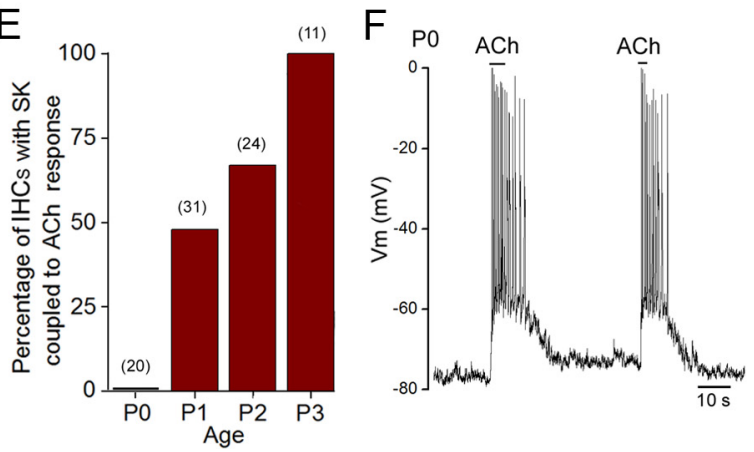

Figure 2. Development of the coupling of $n A C h R s$ and SK channels in apical IHCs. $\boldsymbol{A}, \boldsymbol{B}$, Current voltage relationships of $A C h$-activated currents in $\mathrm{HCS}$ at $\mathrm{PO}(\boldsymbol{A})$ and $\mathrm{P} 2(\boldsymbol{B})$. Holding potentials $\left(V_{\mathrm{h}}\right)$ indicated at the right margin of each recording. Every $3 \mathrm{~min}, 1 \mathrm{~mm}$ ACh was applied for $30 \mathrm{~s}$. At P0, ACh-activated currents were inward at $-94 \mathrm{mV}$ to $-34 \mathrm{mV}$, whereas at P2, ACh-activated currents were inward at $-94 \mathrm{mV}$, multiphasic at $-64 \mathrm{mV}$, and outward at $-34 \mathrm{mV}$. C, I-V relations of the two IHCs shown in $\boldsymbol{A}$ and $\boldsymbol{B}$ show different reversal potentials at $\sim 0 \mathrm{mV}(\mathrm{PO})$ and $\sim-60 \mathrm{mV}$ (P2). For the IHC at P2, the current amplitude was measured at the time indicated by an arrowhead in $\boldsymbol{B}$. D, At $-34 \mathrm{mV}, 1 \mathrm{~mm}$ ACh activates an outward current (top trace). In the presence of $300 \mathrm{~mm}$ apamin, this outward current is blocked (the SK current) and an inward current is unmasked (the nAChR current) (bottom trace). Representative recording here obtained at P1. E, Percentage of IHCs with an outward current at $-34 \mathrm{mV}$ (indicating coupling of SK channels to the ACh response) in response to application of $1 \mathrm{~mm} A C h$ at different ages. In parenthesis, number of IHCs studied. $\boldsymbol{F}$, At PO, application of $1 \mathrm{~mm}$ ACh induces depolarization of the $\mathrm{HHC}$ membrane potential and in this example, firing of $\mathrm{Ca}^{2+}$ action potentials.

$(I-V)$ relations while applying ACh to IHCs at holding potentials between $-94 \mathrm{mV}$ and $+56 \mathrm{mV}$.

At $\mathrm{P} 0$, the $I-V$ relation was almost linear and ACh-evoked currents reversed in sign at $\sim 0 \mathrm{mV}(n=4)$ (Fig. $2 A, C)$. However, at $\mathrm{P} 1$ and $\mathrm{P} 2$, in a subset of IHCs, the ACh response reversed between $-64 \mathrm{mV}$ and $-34 \mathrm{mV}$ and had a local maximum between -34 and $-4 \mathrm{mV}$, suggesting that a calcium-dependent potassium current was involved in the response (Art et al., 1984; Housley and Ashmore, 1991; Fuchs and Murrow, 1992b; Glowatzki and Fuchs, 2000) (Fig. 2 B,C). At $-34 \mathrm{mV}, 300 \mathrm{nM}$ apamin, a peptide toxin specific for SK channels, eliminated the ACh-evoked outward current, leaving a small inward current $(\mathrm{P} 1-\mathrm{P} 3 ; n=6)$ (Fig. 2D), consistent with the hypothesis that the ACh-activated current is mediated by a combination of nAChRs and SK channels in early postnatal apical IHCs. To quantify the percentage of IHCs that exhibited an SK component in the ACh response, we tested whether ACh application caused an inward current (no SK involved) or outward current (SK involved) at a holding potential of $-34 \mathrm{mV}$ (Fig. 2D). At P0, none of the ACh responses included SK $(n=20)$ (Fig. 2E). From P1 to P3, the percentage of ACh responses with an SK component increased from 50\% to $100 \%$.

Accordingly, when monitoring the IHC membrane potential in current clamp, application of ACh at P0/P1 caused depolarization of the IHC $(n=5)$ and could elicit action potentials that are mainly driven by calcium (Kros et al., 1998; Marcotti et al., 2003) in these very young IHCs (Fig. $2 \mathrm{~F}$ ). On the other hand, at older postnatal ages (P7-P13), application of ACh or activation of efferent inputs hyperpolarizes the IHC due to the activation of potassium efflux through SK2 channels and terminates ongoing calcium action potentials (Glowatzki and Fuchs, 2000; Goutman et al., 2005).

nAChR clusters at the IHC appear at P1 and increase in number during the first postnatal week

To study the localization of nAChRs in the forming synapse in the absence of reliable antibodies specific for $\alpha 9$-containing nAChRs, we used fluorescently labeled $\alpha$-bungarotoxin (Alexa Fluor 488 conjugated $\alpha$-Btx). The affinity of $\alpha$-Btx for $\alpha 9$ containing nAChRs has been well characterized (Elgoyhen et al., 1994, 2001; Sgard et al., 2002; Hone et al., 2009). Whereas in the skeletal muscle preparation $\alpha$-Btx binds almost irreversibly to $\alpha 1 \mathrm{nAChRs}$, the interaction of $\alpha$-Btx with $\alpha 9$-containing $\mathrm{nAChRs}$ is reversible (Elgoyhen et al., 2001), requiring special procedures to observe specific labeling of hair cells. We briefly incubated freshly excised apical cochlear turns at P0, P1, P2, P3, and P8 with Alexa Fluor 488 conjugated $\alpha$-Btx and immediately assessed $\alpha$-Btx binding to IHCs with confocal microscopy (see Materials and Methods) (Fig. 3A). This method does not involve permeabilization and therefore only nAChRs located at the plasma membrane can be bound by the competitive antagonist $\alpha$-Btx. IHCs were labeled with FM4-64FX (Fig. 3A), a fluorescent lipophilic stryryl dye that can permeate the mechano-transduction and $\mathrm{P} 2 \mathrm{X}$ receptor channels of hair cells and becomes intensely fluorescent when associated with the outer leaflet of the surface membrane (Seiler and Nicolson, 1999; Self et al., 1999; Gale et al., 2001; Meyer et al., 2001; Crumling et al., 2009). Approximately 10 IHCs were analyzed per tissue sample, and 3-5 tissue samples were taken from at least three different litters.

At P0, no $\alpha$-Btx labeling was detected above background in 41 IHCs (Fig. 3A). At P1, clusters of $\alpha$-Btx labeling were detected in $34 \%$ of IHCs $(n=50)$ and by P3, in all IHCs studied $(n=30)$ (Fig. $3 A, C$ ). Our data are consistent with a study by Osman et al. (2008), describing $\alpha$-Btx-labeled nAChR clusters in rat IHCs at P1. We found discrete clusters of $\alpha$-Btx labeling most commonly in the basolateral region of the IHC, at the level of the nucleus and below (Fig. 3A, arrowheads). A few puncta were also noticeable above the nucleus of the IHCs (Fig. $3 A$, arrow). The diameter of the clusters was in the range of $0.5 \mu \mathrm{m}$. For each age, the average number of clusters observed per IHC was determined (including only the IHCs that had clusters) (Fig. 3D). The average number of clusters per IHC increased with age from 2 clusters/IHC at P1 to 16 clusters/IHC at $\mathrm{P} 8$.

As a control for the specificity of $\alpha$-Btx labeling, we used methyllycaconitine (MLA), a norditerpenoid plant alkaloid, which has been shown to bind to $\alpha$-Btx-binding sites in the brain (Ward et al., 1990). This potent competitive antagonist of $\alpha 7$ nAChRs is also a competitive blocker of $\alpha 9$-containing nAChRs (Verbitsky et al., 2000). In the presence of $120 \mu \mathrm{M}$ MLA, the 

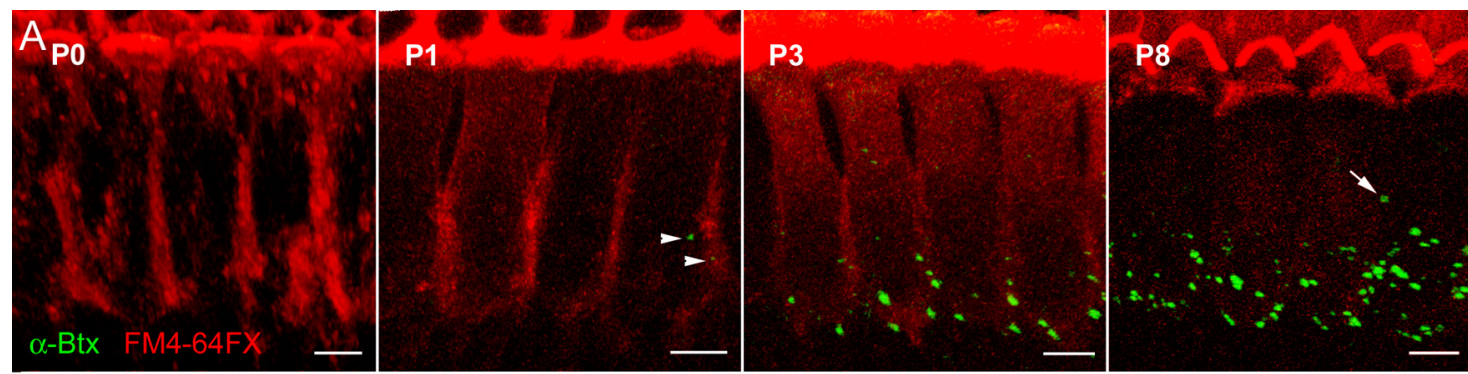

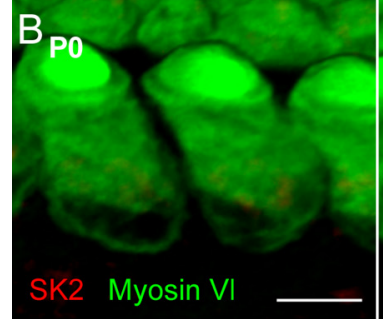

C

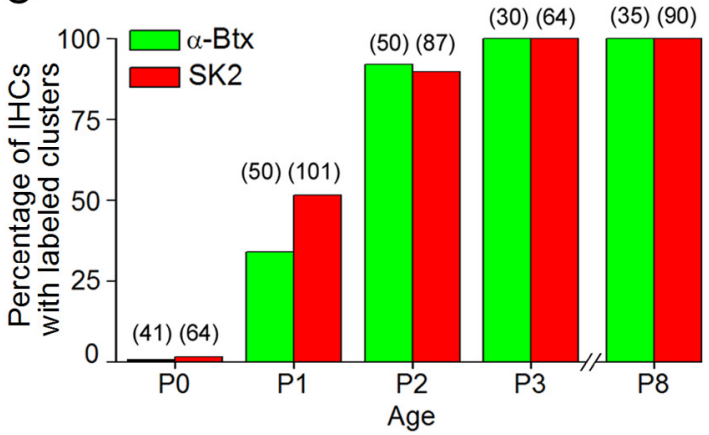

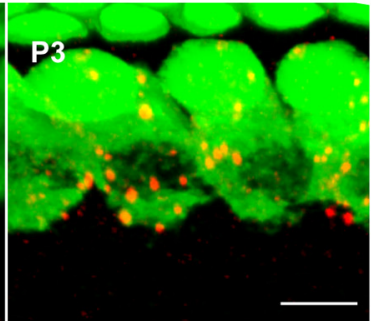

D

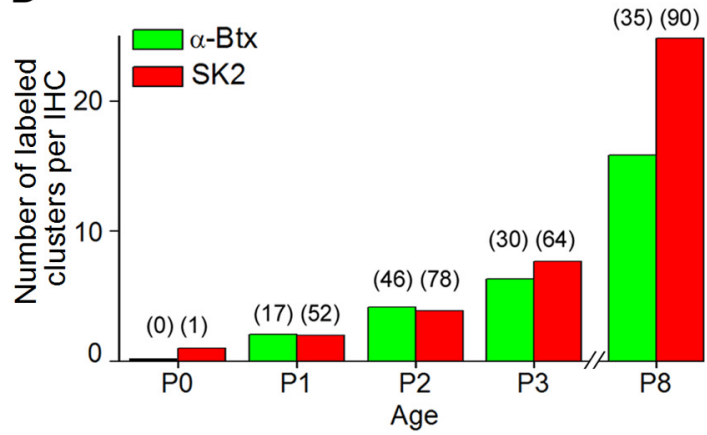

Figure 3. $\mathrm{nAChRs}$ and SK2 clusters appear in apical IHCS at P1 and increase in number during the first postnatal week. $\boldsymbol{A}$, Three-dimensional reconstruction after confocal analysis of ex vivo cochlear preparations labeled with Alexa Fluor 488 conjugated $\alpha$-Btx (green), to detect the nAChRs, and FM4-64FX, a fluorescent lipophilic stryryl dye, to visualize the IHCs (red). $\boldsymbol{B}$, In parallel, SK2 immunoreactivity (red) was studied in the fixed contralateral ear. Myosin VI immunoreactivity (green) was used to label the IHCs. $\boldsymbol{A}, \boldsymbol{B}$, Representative examples obtained from P0, P1, P3, and P8 rats. From P1 on, discrete clusters of $\alpha$-Btx and SK2 labeling were detectable, mostly distributed in the basal region of the IHC at the level of the nucleus and below (arrowheads). A few clusters were noticeable above the nucleus of the IHCs (arrows). Scale bars, $5 \mu \mathrm{m}$. C, $\boldsymbol{D}$, For each labeling, the percentage of IHCs with such clusters was quantified $(\boldsymbol{C})$, as well as the number of clusters per IHC for the IHCS with clusters $(\boldsymbol{D})$ at the different ages. In parentheses, the number of IHCs analyzed is shown.

number of $\alpha$-Btx clusters we observed decreased by $94 \%$ (P3; $n=$ 3 tissue samples).

In summary, we found clusters of $\alpha$-Btx labeling in IHCs starting at $\mathrm{P} 1$. However, at $\mathrm{P} 0, \mathrm{ACh}$ receptor currents were recorded in $90 \%$ of IHCs tested, indicating that nAChRs must be present in the IHC plasma membrane already at $\mathrm{P} 0$. These results suggest that $\mathrm{nAChRs}$ at $\mathrm{P} 0$ are below the detection threshold of the labeling technique used here. A likely explanation is that $\mathrm{nAChRs}$ at P0 are not clustered yet. Alternatively, if they were clustered, the concentration of nAChRs per cluster must be below detection threshold.

\section{SK2 channel clusters appear with a time course similar to that of $\mathbf{n A C h R}$ clusters}

In parallel to the nAChR labeling, we tested for the developmental appearance of SK2 channel immunoreactivity using an SK2specific antibody. For most preparations, tissue from one ear was used for $\alpha$-Btx labeling and from the contralateral ear for SK2 labeling. At P0, no SK2 labeling was found in most IHCs $(63 / 64)$ (Fig. $3 B-D$ ). Clusters of SK2 immunoreactivity were identified at P1 in $51 \%$ of IHCs $(n=101)$, in $90 \%$ of IHCs at P2 $(n=87)$, and at later ages, in $100 \%$ of IHCs studied. Again, these clusters of immunoreactivity were mostly distributed in the basal region of the IHC at the level of the nucleus and below, and a few dots were noticeable in the region above the nucleus (Fig. $3 B$, arrowheads and arrows, respectively). The average number of clusters per IHC increased with age, from 2 clusters/IHC at P1 to 25 clusters/ IHC at P8. From P3 on, a few clusters of SK2 immunoreactivity were also visible outside the IHC, but close to its basolateral region (data not shown), suggesting that SK2 expression at P3 and P8 may not be restricted to the IHC.

The developmental acquisition of SK2 channel clusters and $\mathrm{nAChR}$ clusters shows a similar time course. This parallel development measured with different methods gives confidence that they reflect the formation of the efferent synapse. Second, it suggests that SK channels are involved early on in the process of efferent synapse formation, coincident with the formation of nAChR clusters.

\section{Cholinergic efferent synaptic currents in IHCs appear at P1 and are coupled to SK}

To determine the onset of cholinergic synaptic activity at the IHC, we activated transmitter release from efferent terminals by depolarizing the efferent fibers with a high concentration of extracellular potassium ( $80 \mathrm{~mm}$ ) for $4 \mathrm{~min}$ (Glowatzki and Fuchs, 2000; Katz et al., 2004). This relatively long application time was used to ensure observation of synaptic currents, as these sometimes activated only after considerable delays at these young ages. 
A po

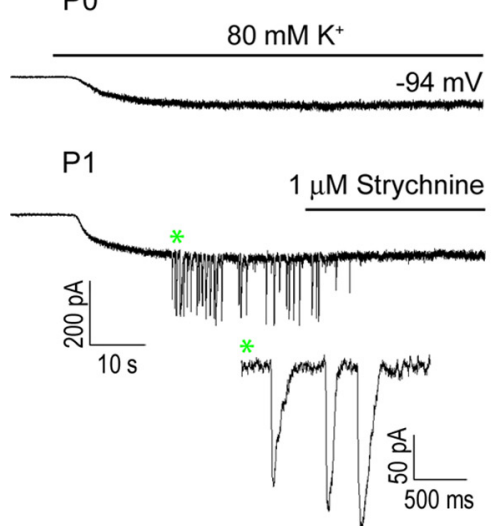

C

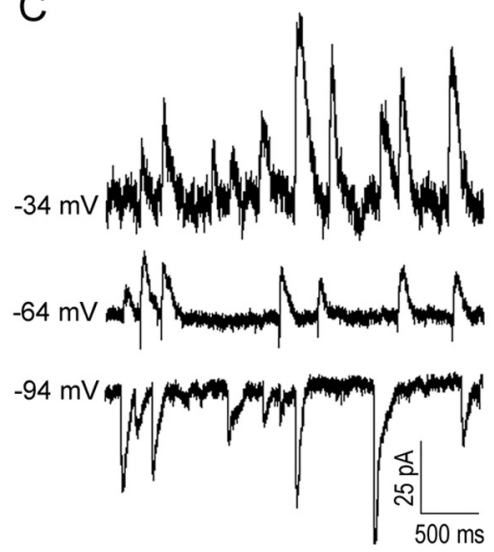

B

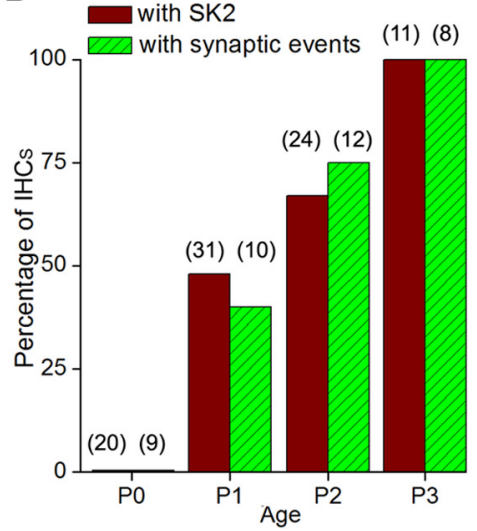

D

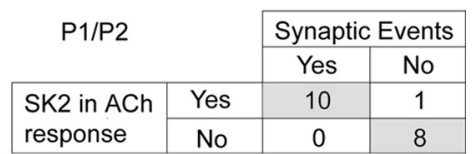

Figure 4. Efferent synaptic currents in apical IHCS appear at P1 and are coupled to SK. A, IHC currents evoked by application of an external solution containing $80 \mathrm{~mm} \mathrm{~K}^{+}$; holding potential $-94 \mathrm{mV}$. No synaptic current could be elicited at P0; only a steady inward current was noticeable (in response to the change of the potassium equilibrium potential from $-81 \mathrm{mV}$ to $-16 \mathrm{mV}$ ). From P1 on, application of $80 \mathrm{~mm} \mathrm{~K}^{+}$evoked synaptic currents (asterisk) in a subset of IHCs. These currents were completely and reversibly blocked by $1 \mu \mathrm{m}$ strychnine. $\boldsymbol{B}$, Percentage of IHCs with synaptic events activated during a 4 min superfusion with external solution containing $80 \mathrm{~mm} \mathrm{~K}^{+}$, studied at different ages. In parentheses, the number of IHCs studied is shown. For comparison, the percentage of IHCs with an SK component in the ACh response is shown (same data as in Fig. 2E). C, Spontaneous synaptic currents recorded in an $\mathrm{IHC}$ at different holding potentials. Currents are inward at $-94 \mathrm{mV}$, biphasic at $-64 \mathrm{mV}$, and outward at $-34 \mathrm{mV}$, indicating an SK component. $\boldsymbol{D}$, Correlation of the presence of SK currents and efferent synaptic activity in $\mathrm{IHCs}$. Individual IHCs were tested for an SK component in the ACh response (at $-34 \mathrm{mV}$ holding potential) and for the presence of synaptic currents during a 4 min application of external solution including $80 \mathrm{~mm} \mathrm{~K}^{+}$. Experiments were performed at $P 1$ and $P 2$, the postnatal days during which both these features appear. The occurrence of synaptic events was significantly associated with the presence of an SK component in the ACh response (Fisher's exact test; $p<0.0005$ ).

No synaptic current could be evoked at P0 (9 IHCs tested) (Fig. $4 A, B)$, but $40 \%$ of cells had synaptic currents at P1 $(n=10), 75 \%$ at $\mathrm{P} 2(n=12)$ and $100 \%$ of IHC had synaptic responses at P3 $(n=8)$ and P8 $(n=7)$ (Fig. 4A,B). Synaptic currents were completely blocked by $1 \mu \mathrm{M}$ strychnine $(n=4$; at P1-P2) (Fig. $4 A$ ) and recovered partially after washout. Synaptic currents were also partially and reversibly blocked by $300 \mathrm{~nm} \alpha-\operatorname{RgIA}(n=3$; at P2) (data not shown), as shown before for efferent synaptic currents in older IHCs (Ellison et al., 2006).

Sometimes, spontaneous synaptic currents occurred in the normal extracellular solution (5.8 mm potassium) (Fig. 4C). Similar to the IHC's response to ACh application, spontaneous synaptic currents were inward at $-94 \mathrm{mV}$, biphasic at $-64 \mathrm{mV}(n=$ $2)$, and outward at $-34 \mathrm{mV}(n=3$; P2), suggesting that an SK component was present. For spontaneous EPSCs, at P2/P3, at $-94 \mathrm{mV}$, EPSCs amplitudes were $17.5 \pm 2.4 \mathrm{pA}$ (mean \pm SE; $n=$ 5 IHCs, 1074 EPSCs analyzed). The 10-90\% EPSC rise times were $7.9 \pm 0.9 \mathrm{~ms}$ and time constants of decay were $61.2 \pm 4.7 \mathrm{~ms}$ ( $n=5$ IHCs; 740 EPSCs analyzed). Together, these data suggest

that at the developmental onset of the efferent response, synaptic currents in IHCs are mediated by $\alpha 9$-containing $\mathrm{nAChRs}$ in combination with calcium-dependent (SK2) potassium channels, as has been shown already for older ages (Glowatzki and Fuchs, 2000). To test for a correlation between the appearance of SK and synaptic currents, rather than looking for the SK component in synaptic currents, we measured the larger response to ACh application and tested whether it included a SK component (indicated by an outward rather than inward current at $-30 \mathrm{mV}$ ). In the same IHCs, we tested whether synaptic currents could be activated with $80 \mathrm{~mm}$ potassium at P1/P2. This association between the presence of synaptic activity and of SK channels was statistically significant (Fig. $4 D$; Fisher's exact test; $p<0.0005$ ). When SK was not present in the ACh response, no synaptic current was recorded $(n=8)$. However, 10 of 11 IHCs that exhibited an SK component in the ACh response also presented synaptic currents during high potassium stimulation.

Significantly, the acquisition of efferent synaptic currents follows a time course matching that of the appearance of nAChRs and SK2 channel clusters in the hair cell plasma membrane. The clustering of both of these postsynaptic channels and the onset of synaptic function go hand in hand.

\section{The onset of efferent synaptic function follows a similar sequence in $\mathrm{OHCs}$ as in IHCs}

Earlier studies on OHCs isolated from the basal and medial turns of rat and gerbil cochleae found ACh-evoked currents as early as P6 and showed that the percentage of OHCs exhibiting an ACh response increased over time (Dulon and Lenoir, 1996; He and Dallos, 1999). Also, for rat OHCs, the percentage of cells with an SK current coupled to the ACh response increased with development (Dulon and Lenoir, 1996). To test whether the appearance of an SK component in the ACh response correlates with the onset of efferent synaptic activity in OHCs, we first reassessed the development of the ACh response by recording from OHCs in excised basal cochlear turns (including $\sim 35 \%$ of the cochlear coil, measured from the base).

From $\mathrm{P} 6$ to $\mathrm{P} 10$, the fraction of OHCs exhibiting a response to a puff application of $1 \mathrm{~mm}$ ACh progressively increased from 15\% at $\mathrm{P} 6$ to $93 \%$ at $\mathrm{P} 10$ (Fig. $5 \mathrm{~A}$ ). In some OHCs, the current voltage relationship of the ACh response reversed near $0 \mathrm{mV}(n=5)$, while in other OHCs, the ACh-evoked current reversed near -60 $\mathrm{mV}(n=5)$ (Fig. $5 B)$. In the latter case, outward currents at negative holding potentials could be fully blocked by $300 \mathrm{nM}$ apamin (Fig. 5B), suggesting that these ACh responses in prehearing basal OHCs included an SK component (Oliver et al., 2000; Marcotti et al., 2004). These results differ from those ob- 

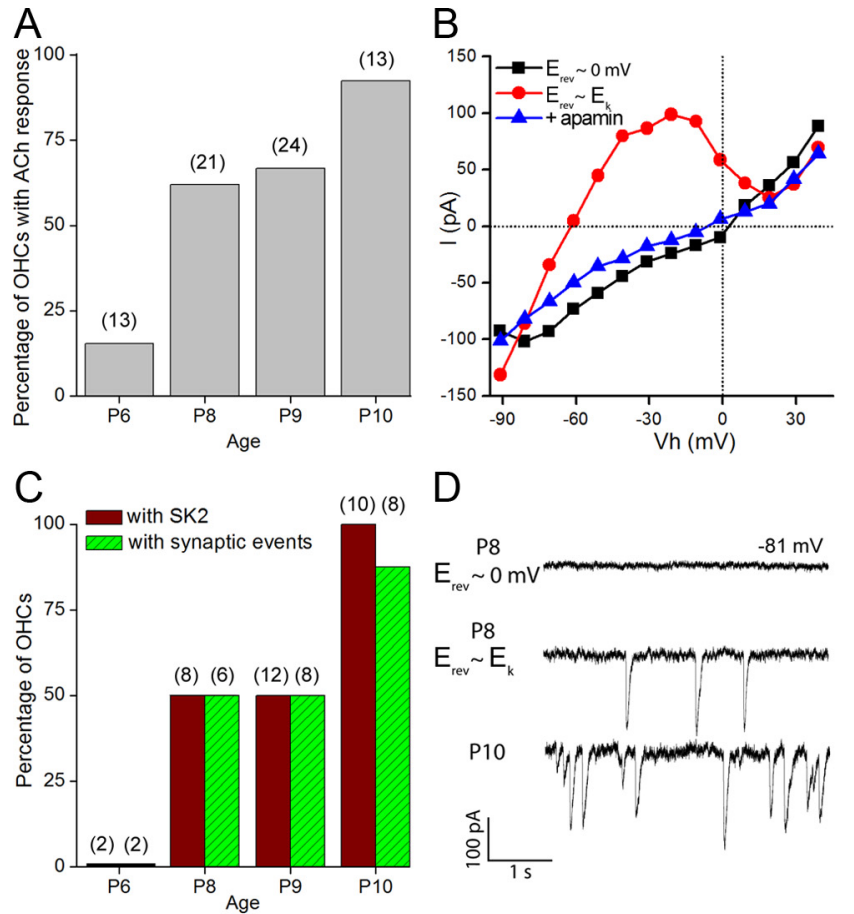

$\mathrm{D}$
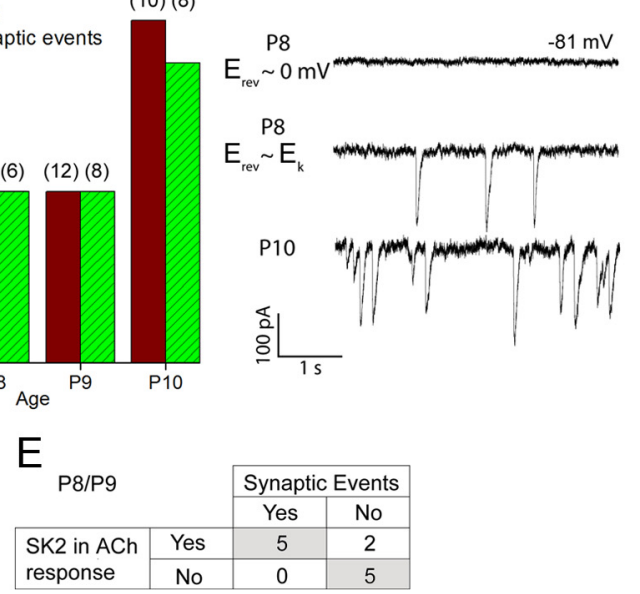

Figure 5. The onset of efferent synaptic function in $\mathrm{OHCs}$ follows a similar sequence of events as in IHCs. $A, B$, The percentage of basal $0 H C s$ with a response to $A C h$ increased from P6 to P10. $\mathrm{OHCs}$ were voltage-clamped at $-81 \mathrm{mV}$ and $\mathrm{ACh}$ was locally puff-applied for $100-500 \mathrm{~ms}$. $\boldsymbol{B}$, The current voltage relationships of the ACh response reversed either at $\sim 0 \mathrm{mV}(n=5)$ or at $\sim-60 \mathrm{mV}(n=6)$ in different $\mathrm{OHCs}$. In $\mathrm{OHCs}$ reversing at $-60 \mathrm{mV}, 300 \mathrm{~nm}$ apamin blocked the outward currents between -60 and $0 \mathrm{mV}$, suggesting that an SK current had been present $(n=6)$. Average values are shown. C, Fraction of $\mathrm{OHCs}$ with an outward current at $-34 \mathrm{mV}$ (indicating coupling of $S K$ to the ACh response) in response to $1 \mathrm{~mm} \mathrm{ACh}$, compared with the fraction of $\mathrm{OHCs}$ with synaptic currents in response to application of extracellular solution with $40 \mathrm{~mm} \mathrm{~K}^{+}$(performed in separate experiments). In parentheses, the number of $\mathrm{OHCs} \mathrm{studied} \mathrm{is}$ shown. $\boldsymbol{D}$, Sample traces of synaptic currents activated by application of extracellular solution with $40 \mathrm{~mm}$ potassium. At $\mathrm{P} 8$, in an $\mathrm{OHC}$ with the $\mathrm{ACh}$ response reversing at $\sim 0 \mathrm{mV}$, no synaptic current was found. At the same age, in an $\mathrm{OHC}$ with the ACh response reversing at $\sim-60 \mathrm{mV}$, synaptic activity appeared at a low rate. At P10, synaptic events occurred at a higher rate. $\boldsymbol{E}$, Correlation of the presence of $\mathrm{SK}$ currents and efferent synaptic activity in $\mathrm{OHCs}$. Individual $\mathrm{OHCS}$ were tested for an SK component in the ACh response (at $-34 \mathrm{mV}$ holding potential) and for the presence of synaptic currents during application of external solution including $40 \mathrm{~mm} \mathrm{~K}^{+}$. Experiments were performed at $\mathrm{P} 8$ and $\mathrm{P9}$, the postnatal days during which both these features appear. The occurrence of synaptic events was significantly associated with the presence of a SK component in the ACh response (Fisher's exact test; $p<0.05$ ).

tained in older animals (P21), in which ACh-gated $\mathrm{K}^{+}$currents of basal OHCs were insensitive to apamin and rather were blocked by iberiotoxin (IBTX), a BK channel blocker (Wersinger et al., 2010). At P6, only 2 of 13 OHCs responded to ACh and these had no SK component. From P8 to P10, an increasing fraction of ACh-responsive OHCs had an SK component [50\% at P8 $(n=8) ; 50 \%$ at $\mathrm{P} 9(n=12)$, and $100 \%$ at $\mathrm{P} 10(n=10)$ ] (Fig. $5 C)$.

Next, we assessed the development of efferent synaptic activity in OHCs using extracellular solution with $40 \mathrm{~mm}$ potassium to evoke release from efferent endings. Evoked synaptic events occurred at relatively low rates of release that increased with age. Rates of release were 0.53 events/s at P8 $(n=3), 0.63$ events/s at P9 $(n=2)$, and 1.68 events/s at P10 $(n=6)$ (Fig. $5 D)$, measured in recordings with $>3 \mathrm{~min}$ of evoked release. Synaptic activity could be evoked in $50 \%$ of ACh-positive OHCs at P8 $(n=6)$ and P9 $(n=8)$ and in $87.5 \%$ at P10 $(n=8)$ (Fig. $5 C)$. In a subset of cells that showed no synaptic activity, in addition to $40 \mathrm{~mm}$ potassium, $80 \mathrm{~mm}$ potassium was also tested, without any different effect (P8, $n=2$; P9, $n=2)$. Again, like in IHCs, the correspondence between synaptic activity and the presence of SK channels was statistically significant (Fig. $5 E$; Fisher's exact test; $p<0.05$ ). When SK was not present, no synaptic current was recorded $(n=$ 5). However, five out of seven OHCs that exhibited an SK component in the ACh response, also presented synaptic currents during high potassium stimulation.

\section{Discussion}

\section{Efferent synapse formation at the IHC}

Efferent innervation originating from the superior olivary complex arrives in close vicinity to the IHCs around birth in the mouse and rat cochlea $\sim 2$ weeks before hearing onset (Sobkowicz and Emmerling, 1989; Cole and Robertson, 1992; Merchán Pérez et al., 1994; Bruce et al., 2000) (for review, see Simmons, 2002; Simmons et al., 2011). Here we charted the onset of this efferent input and examined the functional characteristics of the developing cholinergic response in hair cells. We show that in the apex of the cochlea, nAChRs composed of $\alpha 9$ and/or $\alpha 9 \alpha 10$ subunits are present and functional at the plasma membrane of the IHCs at the day of birth (P0). $\alpha 9$ mRNA has been detected in rat IHCs from E18 on (Luo et al., 1998; Simmons and Morley, 1998) and $\alpha 10$ mRNA from E21 on (Morley and Simmons, 2002), just shortly before ACh-activated currents can be recorded at P0. It is likely that the onset of $\alpha 10$ expression initiates the expression of $\alpha 9 \alpha 10$ heteromeric nAChRs that mediate responses large enough for detection in these recordings. This would be consistent with earlier work showing that in oocyte expression system, ACh responses produced by $\alpha 9 \alpha 10$ coexpression are many times larger than those produced by $\alpha 9$ alone (Elgoyhen et al., 2001). It remains possible that the relative contribution of $\alpha 10$ subunits might change during the early postnatal development, for example due to further upregulation, but the small size of the currents we recorded at early ages in rat does not allow us to discriminate properties of $\alpha 9$ versus $\alpha 9 \alpha 10$ as it can be done in oocytes (Elgoyhen et al., 2001), and thus does not allow us to conclude on their relative contribution in the early ACh response.

At P0, the ACh response includes no current through SK2 channels, but only that through the cation-selective nAChR itself. Both the small size of the response and the lack of visible $\alpha$-Btx labeling at this age suggest that the nAChRs are present at low density on the surface of IHCs. $\alpha$-Btx labeling did not reveal a "prepatterning" of nAChR clusters as described in vertebrate skeletal neuromuscular junction (for review, see Sanes and Lichtman, 2001; Wu et al., 2010), but this may have been below the sensitivity of our detection method. However, from P1 on, punctate $\alpha$-Btx labeling could be detected in a fraction of IHCs, most likely reflecting the presence of high-density clusters of nAChRs. Strikingly, $\alpha$-Btx puncta appeared in parallel with the first clusters of SK2-immunoreactivity.

In keeping with these histological signs of synapse formation, $\mathrm{P} 1$ is also the age at which the first detectable synaptic events appeared, and SK current first appeared in the response to exogenous ACh. This suggests that $\alpha$-Btx clusters most likely reflect newly formed synapses, and that those new synapses include SK2 channels. During this transitional period, every IHC with efferent synaptic activity also produced SK current when exposed to ACh, while cells lacking SK current also lacked synaptic activity, suggesting that SK2 expression may be necessary for the synapse to 
function. Consistent with this idea, spontaneous synaptic events recorded during this period also included an SK component. Comparable results were observed in basal OHCs, where synaptic currents were recorded earliest at P8, reflecting the later arrival of efferent axons to the OHCs (Cole and Robertson, 1992; Merchán Pérez et al., 1994; Bruce et al., 2000).

The cholinergic innervation of hair cells may reflect the common embryological origin of efferent neurons with facial branchial motoneurons (Fritzsch and Nichols, 1993; Bruce et al., 1997; Karis et al., 2001), and, therefore, steps involved in synapse formation may be reminiscent of those at the neuromuscular junction (Sanes and Lichtman, 2001; Wu et al., 2010). For example, three molecules essential for the assembly, clustering, and localization of nAChRs at the skeletal neuromuscular junction, RIC-3, rapsyn, and MuSK, have been detected in hair cells (Osman et al., 2008). As rapsyn interacts with the cytoplasmic loop of $\alpha 9$, nAChR clustering may employ the same scaffolding mechanisms in hair cells and muscle. It is worth noting that mRNA of $\alpha 1$ and $\gamma$ nAChRs subunits has also been localized in mouse hair cells with in situ hybridization during the time period of synapse formation, from just before birth to P4-P7 (Scheffer et al., 2007).

\section{SK2 channels and onset of efferent synaptic function}

A peculiarity of efferent synaptic function in cochlear hair cells, however, is the involvement of SK2 channels early on. This study shows a strong temporal correlation between the appearance and number of nAChRs clusters and SK2 clusters. And, in the same time window, functional coupling of SK2 to nAChRs correlates with the appearance of cholinergic synaptic activity. Together, these observations show that nAChRs first appear, and function, alone in the hair cell plasma membrane. Second, they show that functional expression of SK 2 channels is tightly, perhaps causally, related to the onset of efferent synaptic function. An essential role for SK2 channel participation is also supported by the lack of ACh response and efferent synaptic activity in IHCs of SK2-deficient mice at P6-P12, despite normal levels of $\alpha 9$ and $\alpha 10 \mathrm{nAChR}$ mRNA (Kong et al., 2008). Also relevant to this point, efferent innervation progressively degenerates in SK2-deficient mice (Kong et al., 2008; Murthy et al., 2009). In contrast, even if they are hypertrophied and less numerous compared with those of wild-type animals, the efferent endings are better preserved over time in $\alpha 9$ - and $\alpha 10$-deficient mice (Vetter et al., 1999, 2007). Double knock-out mice deficient in both SK2 and $\alpha 10$ present similar synaptic degeneration compared with SK2 knock-out mice, suggesting that SK2 is the dominant player in synaptic maintenance (Murthy et al., 2009).

SK2 channels could serve as synaptic cornerstones, catalyzing assembly/stabilization of the postsynaptic molecular complex through their binding to $\alpha$-actinin2, a major F-actin crosslinking protein (Lu et al., 2009), by analogy to the anchoring of nAChRs to the actin cytoskeleton at the neuromuscular junction via rapsyn and $\alpha$-actinin (Dobbins et al., 2008). However, given their function as ion channels, it is perhaps more likely that SK2 channels mediate activity-dependent signals essential for synaptic maturation, particularly given their role in "sign reversal" of the synapse. SK2 channels can also be activated in hair cells by calcium influx through voltage-gated channels and may contribute to the repetitive action potential waveform in immature IHCs (Marcotti et al., 2004; Johnson et al., 2007; Kong et al., 2008), thereby generating other activity-dependent signals. It is unknown at present whether SK synaptic function per se, or secondary processes, like action potential activity modulated by SK gating, may be determinants of hair cell functional differentiation.

In the hippocampus, SK2 channels have been shown to be functionally coupled to postsynaptic AMPA receptors of CA1 neurons, where their association is important for limiting the size of the excitatory postsynaptic potentials and spine $\mathrm{Ca}^{2+}$ transients (Ngo-Anh et al., 2005). Also, recent studies have shown that during long-term potentiation, AMPA receptors and SK2 channels were oppositely regulated, using distinct but tightly interregulated endocytic/exocytic pathways (Lin et al., 2010). This suggests that there are activity-dependent feedback loops that control the relative expression of SK2 and its activating $\mathrm{Ca}^{2+}$ permeable receptor.

\section{Efferent synaptogenesis and development of auditory function}

We show that $\alpha 9$-containing receptors are functional at the cell surface before and during the onset of efferent synaptic function. $\alpha 9$-containing receptors have slow rates of desensitization and relatively high affinity for $\mathrm{ACh}\left(\mathrm{EC}_{50} \sim 14 \mu \mathrm{M}\right)$ (Elgoyhen et al., 2001; Le Novère et al., 2002) and so are particularly well suited for volume transmission of ACh before the onset of efferent synaptic function (Zoli et al., 1999). If ACh is released by the outgrowing efferent axons at $\mathrm{P} 0$, this could depolarize IHCs by acting on the "uncoupled" nAChRs, thereby altering the IHC activity pattern and providing instructive signals for synapse formation. However, such an effect will also depend on the relative activity of acetylcholinesterase (AChE), the enzyme that degrades ACh extracellularly. At least in the apex of the cochlea in newborn mice, the expression and activity of several isoforms of AChE have been detected (Emmerling and Sobkowicz, 1988; Sobkowicz and Emmerling, 1989). Also the entrance of $\mathrm{Ca}^{2+}$ through nAChR channels could lead to the activation of cytoplasmic effectors or second messenger pathways, leading to changes in gene expression or protein synthesis of neuronal components (for review, see Zhang and Poo, 2001). Enzymes required for synthesis (ChAT) and vesicular transport of ACh (VAChT) have been detected in the vicinity of the IHCs at P0 (Merchán Pérez et al., 1994; Osman et al., 2008), suggesting that outgrowing efferent axons may be capable of quantal ACh release. Such release has been demonstrated by Hume et al. (1983) and Young and Poo (1983) in growth cones of cholinergic embryonic chick ciliary ganglion neurons and isolated Xenopus embryonic neurons in culture, even in the absence of postsynaptic targets. Functional maturation and the activity patterns of developing efferent neurons remain topics of investigation (Simmons et al., 1996a,b, 1998; Moore et al., 1999; Raji-Kubba et al., 2002) and will ultimately help to understand the presently unknown function of the transient efferent innervation of IHCs during development. Before hearing onset, during the time span of the transient efferent innervation, IHCs fire action potentials that are mainly driven by calcium (Kros et al., 1998; Marcotti et al., 2003) and initiate bursting activity in auditory nerve fibers (Glowatzki and Fuchs, 2002; Tritsch et al., 2007, 2010). The activity patterns in the auditory nerve may specifically influence wiring and refinement in the auditory pathway (Friauf and Lohmann, 1999; Gabriele et al., 2000; Leake et al., 2006; Leao et al., 2006). Any modulation of the IHC membrane potential will affect the firing pattern of the auditory nerve. For example, as a peripheral mechanism, ATP, released from surrounding supporting cells, has been shown to modulate the IHC membrane potential and to activate calcium action potentials in IHCs (Tritsch et al., 2007; Tritsch and Bergles, 2010). Similarly, activity in centrifugal olivocochlear 
neurons may impose efferent modulation on IHC activity and modulate firing properties of auditory nerve fibers (Glowatzki and Fuchs, 2000; Johnson et al., 2011).

\section{References}

Anand R, Peng X, Lindstrom J (1993) Homomeric and native alpha 7 acetylcholine receptors exhibit remarkably similar but non-identical pharmacological properties, suggesting that the native receptor is a heteromeric protein complex. FEBS Lett 327:241-246.

Art JJ, Fettiplace R, Fuchs PA (1984) Synaptic hyperpolarization and inhibition of turtle cochlear hair cells. J Physiol 356:525-550.

Bergeron AL, Schrader A, Yang D, Osman AA, Simmons DD (2005) The final stage of cholinergic differentiation occurs below inner hair cells during development of the rodent cochlea. J Assoc Res Otolaryngol 6:401-415.

Bruce LL, Kingsley J, Nichols DH, Fritzsch B (1997) The development of vestibulocochlear efferents and cochlear afferents in mice. Int J Dev Neurosci 15:671-692.

Bruce LL, Christensen MA, Warr WB (2000) Postnatal development of efferent synapses in the rat cochlea. J Comp Neurol 423:532-548.

Cole KS, Robertson D (1992) Early efferent innervation of the developing rat cochlea studied with a carbocyanine dye. Brain Res 575:223-230.

Crumling MA, Tong M, Aschenbach KL, Liu LQ, Pipitone CM, Duncan RK (2009) P2X antagonists inhibit styryl dye entry into hair cells. Neuroscience 161:1144-1153.

Dobbins GC, Luo S, Yang Z, Xiong WC, Mei L (2008) alpha-Actinin interacts with rapsyn in agrin-stimulated AChR clustering. Mol Brain 1:18.

Dulon D, Lenoir M (1996) Cholinergic responses in developing outer hair cells of the rat cochlea. Eur J Neurosci 8:1945-1952.

Dulon D, Luo L, Zhang C, Ryan AF (1998) Expression of small-conductance calcium-activated potassium channels (SK) in outer hair cells of the rat cochlea. Eur J Neurosci 10:907-915.

Elgoyhen AB, Johnson DS, Boulter J, Vetter DE, Heinemann S (1994) Alpha 9: an acetylcholine receptor with novel pharmacological properties expressed in rat cochlear hair cells. Cell 79:705-715.

Elgoyhen AB, Vetter DE, Katz E, Rothlin CV, Heinemann SF, Boulter J (2001) alpha10: a determinant of nicotinic cholinergic receptor function in mammalian vestibular and cochlear mechanosensory hair cells. Proc Natl Acad Sci U S A 98:3501-3506.

Ellison M, Haberlandt C, Gomez-Casati ME, Watkins M, Elgoyhen AB, McIntosh JM, Olivera BM (2006) Alpha-RgIA: a novel conotoxin that specifically and potently blocks the alpha9alpha10 nAChR. Biochemistry 45:1511-1517.

Emmerling MR, Sobkowicz HM (1988) Differentiation and distribution of acetylcholinesterase molecular forms in the mouse cochlea. Hear Res 32:137-145

Friauf E, Lohmann C (1999) Development of auditory brainstem circuitry. Activity-dependent and activity-independent processes. Cell Tissue Res 297:187-195.

Fritzsch B, Nichols DH (1993) DiI reveals a prenatal arrival of efferents at the differentiating otocyst of mice. Hear Res 65:51-60.

Fuchs PA, Murrow BW (1992a) A novel cholinergic receptor mediates inhibition of chick cochlear hair cells. Proc Biol Sci 248:35-40.

Fuchs PA, Murrow BW (1992b) Cholinergic inhibition of short (outer) hair cells of the chick's cochlea. J Neurosci 12:800-809.

Gabriele ML, Brunso-Bechtold JK, Henkel CK (2000) Plasticity in the development of afferent patterns in the inferior colliculus of the rat after unilateral cochlear ablation. J Neurosci 20:6939-6949.

Gale JE, Marcotti W, Kennedy HJ, Kros CJ, Richardson GP (2001) FM1-43 dye behaves as a permeant blocker of the hair-cell mechanotransducer channel. J Neurosci 21:7013-7025.

Gerzanich V, Anand R, Lindstrom J (1994) Homomers of alpha 8 and alpha 7 subunits of nicotinic receptors exhibit similar channel but contrasting binding site properties. Mol Pharmacol 45:212-220.

Glowatzki E, Fuchs PA (2000) Cholinergic synaptic inhibition of inner hair cells in the neonatal mammalian cochlea. Science 288:2366-2368.

Glowatzki E, Fuchs PA (2002) Transmitter release at the hair cell ribbon synapse. Nat Neurosci 5:147-154.

Gómez-Casati ME, Fuchs PA, Elgoyhen AB, Katz E (2005) Biophysical and pharmacological characterization of nicotinic cholinergic receptors in rat cochlear inner hair cells. J Physiol 566:103-118.
Goutman JD, Fuchs PA, Glowatzki E (2005) Facilitating efferent inhibition of inner hair cells in the cochlea of the neonatal rat. J Physiol 566:49-59.

He DZ, Dallos P (1999) Development of acetylcholine-induced responses in neonatal gerbil outer hair cells. J Neurophysiol 81:1162-1170.

Hone AJ, Whiteaker P, Christensen S, Xiao Y, Meyer EL, McIntosh JM (2009) A novel fluorescent alpha-conotoxin for the study of alpha7 nicotinic acetylcholine receptors. J Neurochem 111:80-89.

Housley GD, Ashmore JF (1991) Direct measurement of the action of acetylcholine on isolated outer hair cells of the guinea pig cochlea. Proc Biol Sci 244:161-167.

Hume RI, Role LW, Fischbach GD (1983) Acetylcholine release from growth cones detected with patches of acetylcholine receptor-rich membranes. Nature 305:632-634.

Johnson SL, Adelman JP, Marcotti W (2007) Genetic deletion of SK2 channels in mouse inner hair cells prevents the developmental linearization in the Ca2 + dependence of exocytosis. J Physiol 583:631-646.

Johnson SL, Eckrich T, Kuhn S, Zampini V, Franz C, Ranatunga KM, Roberts TP, Masetto S, Knipper M, Kros CJ, Marcotti W (2011) Positiondependent patterning of spontaneous action potentials in immature cochlear inner hair cells. Nat Neurosci 14:711-717.

Karis A, Pata I, van Doorninck JH, Grosveld F, de Zeeuw CI, de Caprona D, Fritzsch B (2001) Transcription factor GATA-3 alters pathway selection of olivocochlear neurons and affects morphogenesis of the ear. J Comp Neurol 429:615-630.

Katz E, Elgoyhen AB, Gómez-Casati ME, Knipper M, Vetter DE, Fuchs PA, Glowatzki E (2004) Developmental regulation of nicotinic synapses on cochlear inner hair cells. J Neurosci 24:7814-7820.

Kong JH, Adelman JP, Fuchs PA (2008) Expression of the SK2 calciumactivated potassium channel is required for cholinergic function in mouse cochlear hair cells. J Physiol 586:5471-5485.

Kros CJ, Ruppersberg JP, Rüsch A (1998) Expression of a potassium current in inner hair cells during development of hearing in mice. Nature 394:281-284.

Leake PA, Hradek GT, Chair L, Snyder RL (2006) Neonatal deafness results in degraded topographic specificity of auditory nerve projections to the cochlear nucleus in cats. J Comp Neurol 497:13-31.

Leao RN, Sun H, Svahn K, Berntson A, Youssoufian M, Paolini AG, Fyffe RE, Walmsley B (2006) Topographic organization in the auditory brainstem of juvenile mice is disrupted in congenital deafness. J Physiol 571:563-578.

Le Novère N, Corringer PJ, Changeux JP (2002) The diversity of subunit composition in nAChRs: evolutionary origins, physiologic and pharmacologic consequences. J Neurobiol 53:447-456.

Lin MT, Luján R, Watanabe M, Frerking M, Maylie J, Adelman JP (2010) Coupled activity-dependent trafficking of synaptic SK2 channels and AMPA receptors. J Neurosci 30:11726-11734.

Lu L, Timofeyev V, Li N, Rafizadeh S, Singapuri A, Harris TR, Chiamvimonvat N (2009) Alpha-actinin2 cytoskeletal protein is required for the functional membrane localization of a Ca2 +-activated $\mathrm{K}+$ channel (SK2 channel). Proc Natl Acad Sci U S A 106:18402-18407.

Luo L, Bennett T, Jung HH, Ryan AF (1998) Developmental expression of alpha 9 acetylcholine receptor mRNA in the rat cochlea and vestibular inner ear. J Comp Neurol 393:320-331.

Marcotti W, Johnson SL, Rusch A, Kros CJ (2003) Sodium and calcium currents shape action potentials in immature mouse inner hair cells. J Physiol 552:743-761.

Marcotti W, Johnson SL, Kros CJ (2004) A transiently expressed SK current sustains and modulates action potential activity in immature mouse inner hair cells. J Physiol 560:691-708.

Merchán Pérez A, Gil-Loyzaga P, Eybalin M, Fernández Mateos P, Bartolomé MV (1994) Choline-acetyltransferase-like immunoreactivity in the organ of Corti of the rat during postnatal development. Brain Res Dev Brain Res 82:29-34

Meyer J, Mack AF, Gummer AW (2001) Pronounced infracuticular endocytosis in mammalian outer hair cells. Hear Res 161:10-22.

Moore JK, Simmons DD, Guan Y (1999) The human olivocochlear system: organization and development. Audiol Neurootol 4:311-325.

Morley BJ, Simmons DD (2002) Developmental mRNA expression of the alpha10 nicotinic acetylcholine receptor subunit in the rat cochlea. Brain Res Dev Brain Res 139:87-96.

Murthy V, Maison SF, Taranda J, Haque N, Bond CT, Elgoyhen AB, Adelman JP, Liberman MC, Vetter DE (2009) SK2 channels are required for func- 
tion and long-term survival of efferent synapses on mammalian outer hair cells. Mol Cell Neurosci 40:39-49.

Nenov AP, Norris C, Bobbin RP (1996) Acetylcholine response in guinea pig outer hair cells. II. Activation of a small conductance $\mathrm{Ca}(2+)$ activated K+ channel. Hear Res 101:149-172.

Ngo-Anh TJ, Bloodgood BL, Lin M, Sabatini BL, Maylie J, Adelman JP (2005) SK channels and NMDA receptors form a Ca2+-mediated feedback loop in dendritic spines. Nat Neurosci 8:642-649.

Nie L, Song H, Chen MF, Chiamvimonvat N, Beisel KW, Yamoah EN, Vázquez $\mathrm{AE}$ (2004) Cloning and expression of a small-conductance $\mathrm{Ca}(2+)$ activated $\mathrm{K}+$ channel from the mouse cochlea: coexpression with alpha9/ alpha10 acetylcholine receptors. J Neurophysiol 91:1536-1544.

Oliver D, Klöcker N, Schuck J, Baukrowitz T, Ruppersberg JP, Fakler B (2000) Gating of Ca2+-activated K+ channels controls fast inhibitory synaptic transmission at auditory outer hair cells. Neuron 26:595-601.

Osman AA, Schrader AD, Hawkes AJ, Akil O, Bergeron A, Lustig LR, Simmons DD (2008) Muscle-like nicotinic receptor accessory molecules in sensory hair cells of the inner ear. Mol Cell Neurosci 38:153-169.

Raji-Kubba J, Micevych PE, Simmons DD (2002) The superior olivary complex of the hamster has multiple periods of cholinergic neuron development. J Chem Neuroanat 24:75-93.

Sanes JR, Lichtman JW (2001) Induction, assembly, maturation and maintenance of a postsynaptic apparatus. Nat Rev Neurosci 2:791-805.

Scheffer D, Sage C, Plazas PV, Huang M, Wedemeyer C, Zhang DS, Chen ZY, Elgoyhen AB, Corey DP, Pingault V (2007) The alphal subunit of nicotinic acetylcholine receptors in the inner ear: transcriptional regulation by ATOH1 and co-expression with the gamma subunit in hair cells. J Neurochem 103:2651-2664.

Seiler C, Nicolson T (1999) Defective calmodulin-dependent rapid apical endocytosis in zebrafish sensory hair cell mutants. J Neurobiol 41:424-434.

Self T, Sobe T, Copeland NG, Jenkins NA, Avraham KB, Steel KP (1999) Role of myosin VI in the differentiation of cochlear hair cells. Dev Biol 214:331-341.

Sgard F, Charpantier E, Bertrand S, Walker N, Caput D, Graham D, Bertrand D, Besnard F (2002) A novel human nicotinic receptor subunit, alpha10, that confers functionality to the alpha9-subunit. Mol Pharmacol $61: 150-159$

Simmons DD (2002) Development of the inner ear efferent system across vertebrate species. J Neurobiol 53:228-250.

Simmons DD, Morley BJ (1998) Differential expression of the alpha 9 nicotinic acetylcholine receptor subunit in neonatal and adult cochlear hair cells. Brain Res Mol Brain Res 56:287-292.

Simmons DD, Mansdorf NB, Kim JH (1996a) Olivocochlear innervation of inner and outer hair cells during postnatal maturation: evidence for a waiting period. J Comp Neurol 370:551-562.

Simmons DD, Moulding HD, Zee D (1996b) Olivocochlear innervation of inner and outer hair cells during postnatal maturation: an immunocytochemical study. Brain Res Dev Brain Res 95:213-226.

Simmons DD, Bertolotto C, Kim J, Raji-Kubba J, Mansdorf N (1998) Choline acetyltransferase expression during a putative developmental waiting period. J Comp Neurol 397:281-295.
Simmons DD, Duncan J, Crapon de Caprona D, Fritzsch B (2011) Development of the inner ear efferent system. In: Auditory and vestibular efferents (Ruygo DK, Fay RR, Popper AN, eds). New York: Springer.

Sobkowicz HM, Emmerling MR (1989) Development of acetylcholinesterasepositive neuronal pathways in the cochlea of the mouse. J Neurocytol 18:209-224.

Tritsch NX, Bergles DE (2010) Developmental regulation of spontaneous activity in the Mammalian cochlea. J Neurosci 30:1539-1550.

Tritsch NX, Yi E, Gale JE, Glowatzki E, Bergles DE (2007) The origin of spontaneous activity in the developing auditory system. Nature 450:50-55.

Tritsch NX, Rodríguez-Contreras A, Crins TT, Wang HC, Borst JG, Bergles DE (2010) Calcium action potentials in hair cells pattern auditory neuron activity before hearing onset. Nat Neurosci 13:1050-1052.

Tucker TR, Fettiplace R (1996) Monitoring calcium in turtle hair cells with a calcium-activated potassium channel. J Physiol 494:613-626.

Verbitsky M, Rothlin CV, Katz E, Elgoyhen AB (2000) Mixed nicotinicmuscarinic properties of the alpha9 nicotinic cholinergic receptor. Neuropharmacology 39:2515-2524.

Vetter DE, Liberman MC, Mann J, Barhanin J, Boulter J, Brown MC, SaffioteKolman J, Heinemann SF, Elgoyhen AB (1999) Role of alpha9 nicotinic $\mathrm{ACh}$ receptor subunits in the development and function of cochlear efferent innervation. Neuron 23:93-103.

Vetter DE, Katz E, Maison SF, Taranda J, Turcan S, Ballestero J, Liberman MC, Elgoyhen AB, Boulter J (2007) The alpha10 nicotinic acetylcholine receptor subunit is required for normal synaptic function and integrity of the olivocochlear system. Proc Natl Acad Sci U S A 104:20594-20599.

Ward JM, Cockcroft VB, Lunt GG, Smillie FS, Wonnacott S (1990) Methyllycaconitine: a selective probe for neuronal alpha-bungarotoxin binding sites. FEBS Lett 270:45-48.

Weisstaub N, Vetter DE, Elgoyhen AB, Katz E (2002) The alpha9alpha10 nicotinic acetylcholine receptor is permeable to and is modulated by divalent cations. Hear Res 167:122-135.

Wersinger E, McLean WJ, Fuchs PA, Pyott SJ (2010) BK channels mediate cholinergic inhibition of high frequency cochlear hair cells. PLoS One 5:e13836.

Wu H, Xiong WC, Mei L (2010) To build a synapse: signaling pathways in neuromuscular junction assembly. Development 137:1017-1033.

Yamamoto T, Kakehata S, Yamada T, Saito T, Saito H, Akaike N (1997) Effects of potassium channel blockers on the acetylcholine-induced currents in dissociated outer hair cells of guinea pig cochlea. Neurosci Lett 236:79-82.

Young SH, Poo MM (1983) Spontaneous release of transmitter from growth cones of embryonic neurones. Nature 305:634-637.

Zhang LI, Poo MM (2001) Electrical activity and development of neural circuits. Nat Neurosci [Suppl] 4:1207-1214.

Zoli M, Jansson A, Sykova E, Agnati LF, Fuxe K (1999) Volume transmission in the CNS and its relevance for neuropsychopharmacology. Trends Pharmcol Sci 20:142-150. 